\title{
LA INCIDÈNCIA DE LA DIRECTIVA DE SERVEIS EN EL RÈGIM D'INTERVENCIÓ SOBRE LES ACTIVITATS PER PART DELS ENS LOCALS DES DEL PUNT DE VISTA AMBIENTAL
}

\author{
JOSEP MARIA SABATÉ VIDAL \\ Secretari d'administració local amb habilitació de caràcter estatal \\ Professor associat de Dret Administratiu \\ Universitat Rovira i Virgili \\ josepmaria.sabatev@urv.cat
}

Rebut: 17 d'octubre de 2011 / Acceptat: 29 de novembre de 2011

RESUM: La Directiva 2006/123/CE, relativa als serveis en el mercat interior (Directiva de serveis) i la seva transposició han donat lloc en els darrers temps a un important debat polític i jurídic. L'objectiu principal de la Directiva és el desenvolupament d'un mercat interior de serveis al si de la Unió Europea. Això no obstant, les mesures previstes per assolir-lo, bàsicament la supressió dels obstacles legals i la simplificació dels procediments administratius per a l'establiment i l'exercici d'activitats de servei, han acabant afectant, més enllà de l'objectiu inicial, el règim administratiu de la intervenció i el control sobre les activitats. Una part important d'aquesta intervenció està en mans dels ens locals, especialment en el cas de les activitats que poden tenir incidència ambiental. Mitjançant aquesta nota es pretén donar una breu referència de la incidència que sobre aquest àmbit de competències locals té la Directiva i les normes internes de transposició.

RESUMEN: La Directiva 2006/123/CE, relativa a los servicios en el mercado interior (Directiva de servicios) y su transposición han dado pié en los últimos años a un

\footnotetext{
* Aquest treball s'ha realitzat en el marc del projecte Derecho ambiental y libertad de servicios en el mercado interior: nuevos retos, transformaciones y oportunidades (DER2010-19343), finançat pel Ministerio de Ciencia e Innovación.
} 
importante debate político y jurídico. El objetivo principal de la Directiva es el impulso de un verdadero mercado interior de servicios en el seno de la Unión Europea. No obstante las medidas previstas para ello, básicamente la supresión de los obstáculos legales y la simplificación de los procedimientos administrativos para el establecimiento y ejercicio de actividades de servicio, han afectando finalmente, más allá del objetivo inicial, el régimen administrativo de la intervención y el control sobre las actividades. Una parte importante de esta intervención y control está en manos de los entes locales, especialmente en el caso de las actividades que pueden tener incidencia ambiental. Mediante esta nota se pretende dar una breve reseña de la incidencia que sobre este ámbito de competencias locales tiene la Directiva y las normas internas de transposición.

ABSTRACT: The Directive 2006/123/CE, on services in the internal market (Services Directive), and its transposition in Spain have provoked an important political and legal debate recently. The main goal of the Directive is the development of an internal market of services within the European Union. Nevertheless the due measures to attain it, basically the elimination of legal obstacles and the simplification of administrative procedures for giving permits and controlling services, have affected the traditional command and control system carried out on these activities. An important part of this intervention is conferred to local governments, especially in the case of the activities with environmental impact. I pretend with this note to give a brief reference about how the Directive and the transposition rules affect the local powers.

PARAULES CLAU: Directiva de serveis - ens locals - intervenció sobre les activitats - medi ambient

PALABRAS CLAVE: Directiva de servicios — entes locales — intervención sobre las actividades - medio ambiente

KEY WORDS: 'Services' Directive — local government — authorisation scheme to activities - environment 
Sumari: I. Gènesi, significat i abast de la Directiva 2006/123/CE relativa als serveis en el mercat interior. II. La limitació de les formes d'intervenció pública sobre les activitats de servei. III. Les raons imperioses d'interès general com a fonament de la intervenció administrativa sobre les activitats de servei. IV. Efectes sobre els ens locals de la transposició de la Directiva de serveis a l'ordenament intern espanyol. 1. Efectes derivats de les normes de transposició en l'àmbit de competència estatal. 2. Efectes derivats de les normes de transposició en l'àmbit de competències de la Generalitat de Catalunya. V. La necessària reconversió de la intervenció dels ens locals sobre les activitats amb incidència ambiental. VI. Bibliografia.

\section{GÈNESI, SIGNIFICAT I ABAST DE LA DIRECTIVA 2006/123/CE RELATIVA ALS SERVEIS EN EL MERCAT INTERIOR.}

El 13 de gener de 2004 la Comissió Europea va presentar la proposta de Directiva relativa als serveis en el mercat interior ${ }^{1}$, més coneguda com a Directiva Bolkestein mercès al nom del comissari holandès Frits Bolkestein, responsable de la seva redacció entre els anys 1999-2004. L'objectiu d'aquest text era fer efectiu un veritable mercat interior de serveis i crear un marc jurídic que suprimís els obstacles que poden dificultar la llibertat d'establiment i prestació de serveis a nivell europeu.

Per tal de garantir aquelles llibertats, la proposta preveia mesures de simplificació administrativa (creació de finestretes úniques, tramitació per via electrònica), l'establiment de principis que han de respectar els règims d'autorització de les activitats de servei, i especialment la prohibició de requisits jurídics restrictius en els ordenaments dels estats membres. En relació a la supressió d'obstacles que s'oposen a la lliure circulació dels serveis, la proposta de Directiva preveia com a mesura més cridanera l'establiment del "principi del país d'origen", pel qual el prestador estaria subjecte únicament a la llei de l'estat membre en el qual es trobi establert, sense que les autoritats dels altres estats puguin d'imposar-li restriccions a causa del seu origen. Allò que es volia protegir mitjançant aquest principi era el dret dels destinataris a utilitzar serveis prestats per gestors amb seu a d'altres estats, sense comportaments discriminatoris per part de les autoritats públiques dels països on resideixen els usuaris.

Amb la finalitat d'establir entre els estats membres la confiança recíproca necessària per a l'aplicació d'aquest règim, la proposta de Directiva de Serveis preveia una harmonització de les seves legislacions que garantís una protecció equivalent de l'interès general en qüestions essencials, com la protecció dels consumidors; el reforçament de l'assistència recíproca entre les autoritats dels estats membres, per tal de

\footnotetext{
${ }^{1}$ Proposta de Directiva del Parlament Europeu i del Consell relativa als serveis en el mercat interior, 13 de gener de 2004, COM (2004) 2 final.
} 
garantir un control eficaç de les activitats de servei; mesures de foment de la qualitat dels serveis, com la certificació d'activitats, les cartes de qualitat, etc., i el foment dels codis de conducta, especialment sobre les comunicacions comercials de les professions regulades.

La proposta de Directiva de Serveis va generar però certs recels, especialment en relació amb el "principi del país d'origen” pel perill de “dumping jurídic" que podria comportar. Aquesta controvèrsia a més va coincidir en el temps amb la tramitació del Tractat pel qual s'establia una Constitució per a Europa ${ }^{2}$ — que incorporava la regulació de la llibertat d'establiment (art. III-137 a 143) i de la llibertat de prestació de serveis (art. III-144 a 150) - En aquest context l'argumentació contra l'espantall del "lampista polonès"3, convertit en icona de la oposició a la liberalització del mercat de serveis, va ser un dels elements determinants perquè la República francesa rebutgés, en referèndum celebrat el 29 de maig de 2005, ratificar el projecte constitucional. El mateix va succeir a Holanda en el referèndum de 1 de juny del mateix any, encara que per motius diferents a la barreja de proteccionisme i propaganda antiliberal que van donar la victòria al "no" francès. El rebuig al procés constitucional europeu va implicar, de retruc, també el del projecte de Directiva de Serveis, atesa 1'oposició que es va fer patent entre un bon nombre d'europarlamentaris ${ }^{4}$.

Un any més tard, al maig del 2006, i després de diverses temptatives de consens amb textos alternatius, el Consell Europeu celebrat a Brussel-les va donar el vistiplau a la proposta definitiva de Directiva de Serveis, que va ser sotmesa a debat i aprovació del Parlament Europeu el novembre del 2006, i fou aprovada pel propi Consell el 12 de desembre $^{5}$. Del text definitiu havien caigut algunes mesures (especialment el principi del "país d'origen") i se'n havien modificat d'altres, no obstant, la seva essència es

\footnotetext{
${ }^{2}$ Tractat de Lisboa pel que es modifiquen el Tractat de la UE i el Tractat Constitutiu de la Comunitat Europea.

${ }^{3}$ El lampista polonès o "le plombier polonais" és una expressió popular que va sintetitzar a França el rebuig a la directiva de Serveis i per extensió al projecte polític constitucional europeu la primavera de 2005. Veieu al respecte Rapport d'information $n^{\circ} 199$ (2007-2008) de M. Jean BIZET fait au nom de la délégation pour l'Union européenne, presentat al Senat francès el 7 de febrer de 2008 (pp. 7 i ss.). Aquest document pot consultar-se elctrònicament a http://www.senat.fr/rap/r07-199/r07-1991.pdf .

${ }^{4}$ Veieu RENYER ALIMBAU, J., FONT MONCLÚS, J.A., i SABATÉ VIDAL, J. M., Criteris per a l'adaptació de la normativa local a la Directiva de Serveis, 2006/123/CE, de 12 de desembre, relativa als serveis en el mercat interior, Càtedra d'Estudis Jurídics Locals Enric Prat de la Riba, Barcelona, 2010, p. 5 i ss.

${ }^{5}$ Publicada al Diari Oficial de la Unió Europea (DOUE) de 27 de desembre de 2006.
} 
mantenia $^{6}$. Quedava així plantada un llavor que havia de germinar en les legislacions dels estats membres mitjançant la simplificació de qualsevol control previ a l'establiment o la prestació de serveis, arribant en la mesura del possible a la seva eliminació. Allò que havia sorgit com un projecte per incentivar la prestació de serveis transnacionals acabarà com veurem afectant al nucli dels sistemes d'intervenció pública sobre les activitats, especialment sobre el règim autoritzatori, com a manifestació més típica de les tècniques de policia administrativa.

La Directiva va entrar en vigor el 28 de desembre de 2006, establint-se un termini de tres anys per a la seva transposició, és a dir el 28 de desembre del 2009. A casa nostra aquesta transposició corresponia fonamentalment al legislador, tant estatal com autonòmic, però com veurem ha afectat i força als ens locals. No en va en els municipis resideixen bona part de les competències relatives a l'establiment d'activitats econòmiques, que d'acord amb l'ampli àmbit d'aplicació establert per l'article 2 de la Directiva, cal considerar serveis en els termes de la mateixa.

\section{LA LIMITACIÓ DE LES FORMES D'INTERVENCIÓ PÚBLICA SOBRE LES ACTIVITATS DE SERVEI.}

Tal i com s'ha dit, la finalitat principal de la Directiva de serveis és el reforçament de la llibertat d'establiment i del mercat interior de serveis, segurament una de les assignatures pendents de la Unió, a causa de la manca fins ara d'una reglamentació general destinada a garantir en aquest àmbit els intercanvis al si de la Unió.

D’aquesta manera l'article 9 de la Directiva és el que recull més clarament aquesta finalitat pel que fa a la llibertat d'establiment. Segons determina aquest article els estats membres no poden condicionar l'establiment d'una activitat de servei i el seu exercici a una autorització o llicència llevat que:

a) el règim d'autorització no sigui discriminatori per al prestador

b) la necessitat d'un règim d'autorització estigui justificat per una raó imperiosa d'interès general, $\mathrm{i}$

\footnotetext{
${ }^{6}$ Sobre aquesta qüestió veieu DE LA QUADRA-SALCEDO FERNANDEZ DEL CASTILLO, T., "Libertad de establecimiento y de servicios: ¿reconocimiento mutuo o país de origen?, Revista española de Derecho Administrativo, núm. 146, 2010, p. 223 i ss.
} 
c) l'objectiu perseguit per aquesta no pugui ser assolit per una mesura menys restrictiva, com és el cas del control a posteriori, perquè la possible intervenció posterior arribaria massa tard per ser efectiva. ${ }^{7}$

A partir d'aquestes previsions la Directiva de Serveis, va més enllà de l'objectiu d'afavorir l'intercanvi en la prestació de serveis al si de la UE. La Directiva opta per un model d'intervenció administrativa en l'àmbit de l'establiment i prestació de serveis basat en la declaració responsable i la comunicació prèvia, models d'origen anglosaxó que es prediquen com afavoridors de la llibertat d'establiment d'activitats i empreses. Un model que sens dubte significa pel ens locals un important canvi de paradigma, tenint en compte la tradicional intervenció de les autoritats locals en l'establiment de les activitats basada en la llicència prèvia.

Els preceptes suara esmentats traspuen una filosofia que impregna tot el text de la Directiva i que gira al voltant d'un eix definit per dues finalitats principals. La primera és sens dubte la desregulació, mitjançant el mandat contingut a la Directiva i adreçat a les autoritats dels estats membres, també a les locals com més endavant veurem, de revisar i posar en qüestió totes les regulacions internes sobre l'establiment i l'exercici d'activitats de servei. La segona, subsidiària de la primera, és la fixació del principi de proporcionalitat com a criteri de validesa de la regulació que s'estableixi en aquesta matèria ${ }^{8}$.

En aquest sentit es posa de manifest una voluntat del legislador europeu de limitar la discrecionalitat dels legisladors nacionals dels estats membres a l'hora d'intervenir en l'establiment i la prestació de serveis, que troba una de les seves màximes expressions en la positivització, o com alguns autors han dit la "codificació", de les anomenades "raons imperioses d'interès general", concepte forjat pel Tribunal de Justícia de la UE, per tal ponderar la validesa dels límits, controls o restriccions de les autoritats dels estats membres a aquesta llibertat. En paraules de S. MUÑOZ MACHADO, “(...) la Directiva de Servicios (...), pese a su apariencia revolucionaria, no hace otra cosa que incorporar al cuerpo de una norma escrita, principios, consideraciones e

\footnotetext{
${ }^{7}$ GONZÁLEZ GARCÍA, J., "La transposition de la Directive services. À propos de deux problèmes: la Directive face au droit primaire et les régimes d'autorisations", ponència presentada al col·loqui que sota el títol La transposition de la directive Services va tenir lloc a Paris el 4 de juny de 2010, organitzat per la Chaire Mutations de l'action publique et du droit public (MADP), Sciencies Po.

${ }^{8}$ Ibid.
} 
interpretaciones de los artículos 43 y 49 del Tratado CE, que ya habían sido hechos en reiteradas ocasiones por el Tribunal de Justicia comunitario"9.

L'esmentada "codificació" és recull a l'article 4.8 amb caràcter general i a l'article 16.2 de la Directiva, en el cas de les causes que poden donar lloc a la limitació de la llibertat d'establiment i prestació de serveis en les relacions transfrontereres, cenyint-se en aquest darrer cas a raons d'ordre públic, de seguretat pública, de salut pública o de protecció del medi ambient.

Hom considera, a la llum dels esmentats preceptes, que tot i que en termes generals es parla de codificació de les raons imperioses d'interès generals és possible també afirmar que la Directiva va més enllà d'allò que seria una simple compilació, ja que de fet en alguns casos, com l'esmentat punt 2 de l'article 16, es pot considerar més restrictiva que no ho ha estat fins ara la jurisprudència del Tribunal de Justícia en aquesta matèria ${ }^{10}$.

El Tribunal europeu ha forjat aquell concepte a partir de diverses sentències que arrenquen fonamentalment de la sentència de 25 de juliol de 1991, en la qual afirma:

"Compte tenu de la nature particulière de la prestation de services dans certains secteurs d'activités, on ne saurait considérer comme incompatibles avec le traité des exigences spécifiques imposées au prestataire, qui seraient motivées par l'application de règles régissant lesdites activités. Toutefois, la libre prestation des services, en tant que principe fondamental du traité, ne peut être limitée que par des réglementations justifiées par des raisons impérieuses d'intérêt général et s'appliquant à toute personne ou entreprise exerçant une activité sur le territoire de l'État destinataire, dans la mesure où cet intérêt n'est pas sauvegardé par les règles auxquelles le prestataire est soumis dans l'État membre où il est établi. En particulier, lesdites exigences doivent être objectivement nécessaires en vue de garantir l'observation des règles professionnelles et d'assurer la protection du destinataire des services et elles ne doivent pas aller au delà de ce qui est nécessaire pour atteindre ces objectifs"

En aplicació d'aquesta doctrina el Tribunal de Justícia ha admès fins ara intervencions administratives en aquest àmbit fonamentades en finalitats que no es troben

\footnotetext{
9 MUÑOZ MACHADO, S., "Ilusiones y conflictos derivados de la Directiva de Servicios", Retos y oportunidades para la transposición de la Directiva de Servicios, Circulo de Empresarios, Madrid, 2009.

${ }^{10}$ GONZÁLEZ GARCÍA, J., "La transposition ...” cit.
} 
contemplades, al menys explícitament, en el text de la Directiva, com són l'ordre social o una política social legítima o la protecció cultural, entre altres.

D'un costat aquesta limitació pot considerar-se positiva, en el sentit d'afavorir al màxim la llibertat d'establiment i prestació de serveis. Però de l'altra també pot considerar-se negativament en el sentit de limitar les raons d'interès públic que poden justificar les limitacions que les autoritats dels estats membres puguin establir en aquesta matèria ${ }^{11}$. Fins i tot es pot observar aquesta restricció com una limitació de les competències de les autoritats dels estats membres en front de les autoritats comunitàries ${ }^{12}$.

Des del meu punt de vista, però, sent perfectament certes i comprensibles aquestes opinions, crec que no és menys cert que les limitacions a la discrecionalitat i la fixació de pautes per al seu exercici és una bona fórmula per prevenir el seu abús i facilitar-ne el control jurisdiccional. De la mateixa manera, la previsió normativa de les raons imperioses d'interès general que poden invocar les autoritats dels estats membres és una mesura necessària per garantir la homogeneïtat dels criteris limitadors de la llibertat d'establiment i lliure prestació de serveis a tota la Unió, sense limitar en cap cas les facultats d'apreciació i concreció de les mateixes per part d'aquestes autoritats.

La fonamentació de les limitacions en d'altres raons, més enllà de les expressades en el text de la directiva podria ser expressió de polítiques particulars de les autoritats dels estats membres, però el cert és que les raons que recull aquella són molt àmplies, reveladores de valors o concepcions polítiques compartides abastament per la ciutadania europea, $\mathrm{i}$ en darrera instància és també sens dubte una opció política fer ús o no d'aquestes raons com a fonament d'una possible limitació. Tot això sense oblidar que aquest comentari només té sentit si ens referim a l'article 16, ja que la llista general de l'article 4.8 de la Directiva no té vocació de ser una llista tancada ${ }^{13}$.

\footnotetext{
${ }^{11}$ DE LA QUADRA-SALCEDO FERNANDEZ DEL CASTILLO, T., "Libertad de establecimiento ..." cit., pp. 239 i ss.

${ }^{12}$ GONZÁLEZ GARCÍA, J., “La transposition ...” cit.

${ }^{13}$ SALVADOR ARMENDÁRIZ, M. A., VILLAREJO GALENDE, H., "La Directiva de Servicios y la regulación de los grandes establecimientos comerciales en Navarra", Revista Jurídica de Navarra, núm. 44, 2007, p. 51.
} 


\section{LES RAONS IMPERIOSES D'INTERÈS GENERAL COM A FONAMENT DE LA INTERVENCIÓ ADMINISTRATIVA SOBRE LES ACTIVITATS DE SERVEI}

Segons ha declarat en reiterada jurisprudència el Tribunal de Justícia, les restriccions a la llibertat d'establiment que siguin aplicables sense discriminació per raó de nacionalitat poden estar justificades por raons imperioses d'interès general, sempre que siguin adequades per garantir la realització de l'objectiu que persegueixen i no vagin més allà del necessari per assolir l'esmentat objectiu (sentències de 10 de març de 2009, Hartlauer, C-169/07, Rec. p.I-1721, apartat 44; de 19 de maig de 2009, Apothekerkammer des Saarlandes i altres, C-171/07 i C-172/07, Rec. p. I-4171, apartat 25, i Blanco Pérez i Ch. Gómez, apartat 61).

Entre aquestes raons imperioses reconegudes pel Tribunal de Justícia hi figura precisament la protecció del medi ambient (sentència de 11 de març de 2010, Attanasio Group, C-384/08, Rec. p. I-0000, apartat 50), també la ordenació del territori (sentencia de 1 de octubre de 2009, Woningstichting Sint Servatius, C-567/07, Rec. p. I-9021, apartat 29), la protecció dels consumidors (sentència de 13 de setembre de 2007, Comisió/Itàlia, C-260/04, Rec. p. I-7083, apartat 27) i d'altres de les que ja s'ha avançat figuren a l'article 4.8 de la Directiva de Serveis. En canvi el Tribunal ha deixat ben clar que els objectius de caràcter merament econòmic no poden constituir una raó imperiosa d'interès general (en aquest sentit, es pot veure la sentència de 15 d'abril de 2010, CIBA, C-96/08, Rec. p. I-0000, apartat 48).

No obstant, cal tenir en compte que, independentment de que existeixi un objectiu legítim per limitar el dret de lliure establiment i prestació de serveis, d'acord amb el Dret de la Unió la justificació d'una restricció de les llibertats fonamentals garantides pel Tractat pressuposa que la mesura pugui garantir l'abast de l'objectiu que persegueix i no vagi més enllà del necessari per assolir-lo (en aquest sentit, va el pronunciament de les sentències de 26 de novembre de 2002, Oteiza Olazábal, C-100/01, Rec. p. I-10981, apartat 43; de 16 d'octubre de 2008, Renneberg, C-527/06, p. I-7735, apartat 81; de 11 de juny de 2009, X i Passenheim-van Schoot, C-155/08 i C-157/08, Rec. p. I-0000, apartat 47, i de 17 de novembre de 2009, President del Consell de Ministres, C-169/08, Rec. p. I-0000, apartat 42). A més, una normativa nacional només es considera adequada per a garantir la consecució de l'objectiu al·legat si respon verdaderament al capteniment per fer-lo efectiu de forma congruent i sistemàtica (en particular, serveixen 
com exemple les sentències Hartlauer, apartado 55, i Presidente del Consiglio dei Ministri, apartat 42) $)^{14}$.

Per tant, a l'empara de l'esmentada jurisprudència i del que preveuen l'article 9 i següents de la Directiva, les autoritats dels estats membres només podran emprar l'autorització o llicència prèvia com a forma d'intervenció sobre les activitats quan aquesta es trobi fonamentada en una raó imperiosa d'interès general. Raó que, com ve reconeixent la jurisprudència i el propi text de la Directiva (article 4.8), pot ser la protecció de medi ambient. Ara bé aquesta raó no pot ser invocada de forma genèrica $\mathrm{i}$ en abstracte sinó que cal que sigui motivada la seva necessitat i proporcionalitat respecte a l'assoliment de l'objectiu perseguit.

\section{EFECTES SOBRE ELS ENS LOCALS DE LA TRANSPOSICIÓ DE LA DIRECTIVA DE SERVEIS A L'ORDENAMENT INTERN ESPANYOL.}

\section{Efectes derivats de les normes de transposició en l'àmbit de competència estatal}

En aquest context i per tal de donar compliment als objectius marcats per la Directiva de Serveis, el Congrés del Diputats va aprovar a finals de 2009 la Llei 17/2009, de 23 de novembre, sobre lliure accés a les activitats de serveis i el seu exercici, anomenada pel govern espanyol "llei paraigües" per tractar-se d'una llei general amb vocació de que els seus preceptes i principis condicionin i inspirin les lleis sectorials en matèria de serveis. Al límit del termini de transposició la cambra legislativa espanyola va aprovar també la Llei 25/2009, de 23 de novembre, de modificació de diverses lleis per a la seva adaptació a la Llei sobre el lliure accés a les activitats de serveis i el seu exercici, coneguda com a "llei òmnibus" pel fet de tractar-se d'una mena de llei de mesures amb la que es modifica de forma puntual totes les disposicions legals que en matèria de competència estatal es troben afectades per la Directiva de Serveis i la Llei 17/2009.

Aquesta transposició de la Directiva de Serveis ha suposat la modificació d'una cinquantena de lleis estatals, una desena de les quals són lleis ambientals, si bé s’ha de

\footnotetext{
${ }^{14}$ Sobre aquest extrem cal recordar també que, si bé correspon a l'Estat membre que invoca una raó imperiosa d'interès general per a justificar una restricció a una llibertat de circulació o establiment, demostrar que la seva normativa es apropiada i necessària para assolir l'objectiu legítim perseguit, aquesta càrrega de la prova no pot arribar fins al punt de que s'exigeixi a l'esmentat estat demostrar de forma positiva que cap altra mesura imaginable permetria assolir aquest objectiu en les mateixes condicions. Veieu en aquest sentit, la sentència de 10 de febrer de 2009, Comissió/Itàlia, apartat 66.
} 
dir que es tracta de modificacions de poc abast, tenint en compte que la protecció ambiental és com s'ha dit una de las raons imperioses d'interès general que permeten imposar o mantenir el règim autoritzatori. Aquestes modificacions es troben establertes als articles 28 a 39 de la Llei 25/2009 i s'agrupen en el capítol I del Títol V, sota la rúbrica "Serveis mediambientals".

Les modificacions son poc rellevants comparades amb les que s'ha introduit en altres sectors normatius. Es tracta de modificacions escassament significatives dirigides, sobre tot, a actualitzar algunes disposicions i a clarificar el règim d'autorització, substituint-lo en alguns casos per declaracions responsables o comunicacions. Concretament, aquesta modificació s'ha dut a terme en matèria d'importació, intermediació i agència en matèria de residus, en matèria d'us comú especial de les aigües continentals, la navegació recreativa en embassaments $i$ en matèria d'usos complementaris i compatibles de les vies pecuàries). Totes elles són matèries on la intervenció local és nul $\cdot$ la o gairebé nul $\cdot 1 a^{15}$.

Des d'un punt de vista general, la novetat més important introduïda per la Llei 25/2009 ve donada per la modificació de la Llei 30/1992, de 26 de novembre de règim jurídic de les administracions públiques i del procediment administratiu comú, que afecta de ple als ens locals. Les disposicions afectades són concretament l'article 43 relatiu al regim del silenci administratiu i l'addició dels nous articles 39 bis, relatiu als principis d'intervenció de les administracions públiques sobre les activitats, i 71 bis, relatiu a la declaració responsable i la comunicació prèvia. Figures aquestes darreres que sota l'impuls de la Directiva es regulen per primer cop de forma general en el dret intern espanyol.

La Llei 25/2009 també va modificar l'article 84 de la Llei 7/1985, de 2 d'abril, reguladora de les bases de règim local, en relació a les formes d'intervenció dels ens locals sobre l'activitat dels ciutadans per tal d'incorporar en la seva redacció els principis derivats de la Directiva i de la Llei 17/2009. En aquest sentit s'incorporen com a formes d'intervenció la declaració responsable i la comunicació prèvia, també el control posterior a l'inici de l'activitat, i s'estableix que la sotmisió a llicència prèvia

\footnotetext{
15 Veieu al respecte PERNAS GARCIA, J.J., “Técnicas preventivas de protección ambiental y normativa de servicios. Análisis particularizado de la evaluación de impacto ambiental y de la ordenación administrativa de la gestión de residuos", Revista Catalana de Dret Públic, núm. 2, 2010, pp. 1-35.
} 
quan es tracti d'activitats de servei només serà possible en la mesura que es compleixin els requisits que al respecte preveu la Llei $17 / 2009^{16}$.

Aquesta disposició es va completar més d'un any més tard amb un article 84 bis i un article 84 ter, introduïts per la Llei 2/2011, de 4 de març, d'economia sostenible. L'article 84 bis determina que, amb caràcter general, l'exercici d'activitats no s'ha de sotmetre a l'obtenció de llicència o un altre mitjà de control preventiu. No obstant això, es poden sotmetre a llicència o control preventiu les activitats que afectin la protecció del medi ambient o del patrimoni historicoartístic, la seguretat o la salut públiques, o que impliquin l'ús privatiu i ocupació dels béns de domini públic, sempre que la decisió de submissió estigui justificada i sigui proporcionada. En cas que hi hagi llicències o autoritzacions concurrents entre una entitat local i alguna altra administració, l'entitat local ha de motivar expressament en la justificació de la necessitat de l'autorització o llicència l'interès general concret que es pretén protegir i que aquest no està ja cobert mitjançant una altra autorització existent.

Es pot dir que la primera part del precepte representa un tomb més en el cargol que apreta l'estructura del nou règim d'intervenció sobre les activitats, mentre la segona part del mateix abunda en les raons ambientals com a fonament de la seva excepció. El darrer incís esdevé un nou requisit per als ens locals a l'hora d'establir mitjançant ordenances o reglaments llicències o autoritzacions de la seva competència.

Pel que fa a l'article 84 ter estableix, com a complement del precepte anterior, que quan l'exercici d'activitats no necessiti autorització habilitadora i prèvia, les entitats locals han d'establir i planificar els procediments de comunicació necessaris, així com els de verificació posterior del compliment dels requisits necessaris perquè les exerceixin els interessats que preveu la legislació sectorial

Encara més recentement el RDL 8/2011, de 1 de juliol, ha vingut ha modificar també els articles 11, 12 i 29 la Llei 16/2002, de 1 de juliol, de prevenció i control integrats de la contaminació, en relació al procediment d'atorgament de l'autorització ambiental, a l'hora que introdueix també algunes novetats de caràcter general, la més destacable de les quals és la continguda a la disposició addicional setena. Aquesta disposició estableix una mena de clàusula residual o de tancament de tots els canvis operats en matèria del règim d'intervenció administrativa local sobre les activitats de servei que literalment

\footnotetext{
${ }^{16}$ Veieu els articles 5 i 6 de la Llei 17/2009.
} 
determina que "a excepció de les autoritzacions que s'imposin en compliment de la legislació de patrimoni de les administracions públiques i d'armes i explosius, les mencions que conté la legislació estatal a les llicències o autoritzacions municipals relatives a l'activitat, funcionament o obertura s'entenen referides als diferents mitjans d'intervenció administrativa en l'activitat dels ciutadans, segons els principis de l'article 39 bis de la Llei 30/1992, de 26 de novembre, de règim jurídic de les administracions públiques i del procediment administratiu comú i recollides a l'article 84.1 de la Llei 7/1985, de 2 d'abril, reguladora de les bases del règim local.”.

\section{Efectes derivats de les normes de transposició en l'àmbit de competències de la Generalitat de Catalunya}

Pel que fa a la Generalitat, la transposició és va dur a terme per una banda mitjançant el Decret 106/2008, de 6 de maig, de mesures per a l'eliminació de tràmits i la simplificació de procediments per facilitar l'activitat econòmica i per l'altra mitjançant el Decret Legislatiu 3/2010, de 5 d'octubre, per a l'adequació de normes amb rang de llei a la Directiva 2006/123/CE, del Parlament i del Consell, de 12 de desembre de 2006. Com en el cas de les competències estatals els canvis normatius en matèria ambiental són en aquestes normes poc significatius. I amb una incidència directa per al món local més aviat escassa llevat de la genèrica modificació dels articles 236 i 238 del Text Refós de la Llei municipal i de règim local de Catalunya, aprovat pel Decret Legislatiu 2/2003, de 28 d'abril, que es refereixen a les modalitats d'intervenció dels ens locals en l'activitat dels ciutadans i a l'ordenació sectorial i a la intervenció administrativa respectivament, en la línia de la modificació operada per la Llei estatal 25/2009, sobre la Llei 7/1985, de 2 d'abril, reguladora de bases del règim local.

En canvi, el Parlament de Catalunya va aprovar la segona meitat del 2009 dues lleis que sense haver estat projectades com normes de transposició de la Directiva de serveis (i fins $i$ tot negant-los en algun cas el propi legislador aquesta funció) són de fet les normes que des del punt de vista del nou model d'intervenció sobre les activitats de serveis més afecten als ens locals ${ }^{17}$.

\footnotetext{
${ }^{17}$ Veieu J. RENYER ALIMBAU, J. A. FONT MONCLÚS i J. M. SABATÉ VIDAL, Criteris per a l'adaptació de la normativa local... cit., p. 39.
} 
La primera d'aquestes lleis és la Llei 11/2009, de 6 de juliol de regulació administrativa dels espectacles públics i les activitats recreatives que fou aprovada, tot i l'advertiment del Consell de Garanties Estatutàries ${ }^{18}$, passant de puntetes sobre aquesta qüestió. La segona és la Llei 20/2009, de 4 de desembre sobre prevenció i control ambiental de les activitats, que podem dir (tot i que els seus redactors van mantenir també el contrari ${ }^{19}$ ) que en part transposa la Directiva o almenys acaba incorporant alguns dels seus principis.

Pel que fa a la Llei 11/2009, hom podrà dir que de fet no es tracta d'una llei ambiental o d'intervenció administrativa ambiental. És cert, però no ho és menys que un dels fonaments de la seva regulació, o en termes de la Directiva de Serveis una de les raons imperioses d'interès general, que esgrimeix la Llei 11/2009 és la protecció de l'entorn urbà, raó íntimament lligada amb la protecció ambiental. Un altra de les raons imperioses d'interès general en les que aquesta llei fonamenta la seva regulació és la protecció de l'interès legítim de tercers, especialment els veïns. Aspecte que una vegada més ens remet de forma col·lateral a la protecció ambiental si tenim en compte que un dels elements de conflicte entre els drets dels veïns i el de la llibertat d'establiment de les activitats recreatives és el soroll.

Així les coses, dos elements d'aquesta llei posats en relació amb la Directiva de serveis destaquen per sobre dels altres. En primer lloc la possibilitat que ofereix als ajuntaments en relació a algunes de les activitats que la llei sotmet a règim de llicència (autorització prèvia en termes de la Directiva) de sotmetre-les al règim de comunicació prèvia. Aquesta previsió que converteix en excepció la comunicació prèvia sembla justament inversa a les previsions de la Directiva. Val a dir no obstant que el desenvolupament reglamentari de la llei, mitjançant el Decret 112/2010, de 31 d'agost, pel qual s'aprova el reglament d'espectacles públics i activitats recreatives dona pràcticament la volta a aquesta previsió, establint com a regla general la comunicació prèvia per un bon nombre d'activitats (articles 124 i 125), reservant de manera més coherent amb la Directiva el

\footnotetext{
${ }^{18}$ El llavors Consell Consultiu de la Generalitat, en el seu dictamen 293, de 26 de maig de 2009, relatiu al projecte de llei va advertir de l'omissió de tota referència a la Directiva de serveis en el mateix i de la necessitat de fer-ho.

${ }^{19}$ Veieu les compareixences relatives a la tramitació parlamentària de la llei de prevenció i control de les activitats que es publiquen al Diari de sessions del Parlament de Catalunya, sèrie C, núm. 588 de 10 de juny de 2009. En el mateix sentit, veieu PERDIGÓ SOLÀ, J., CHOY TARRÉS, A., LIGÜERRE CASALS, J., Comentaris a la Llei 20/2009, de 4 de desembre, de prevenció $i$ control ambiental de les activitats, Generalitat de Catalunya, Departament de Medi Ambient i Habitatge, Barcelona, 2010.
} 
règim de llicència a les activitats que per la seva naturalesa, capacitat, o altres factors facin esdevenir menys efectiva la intervenció posterior ${ }^{20}$.

En segon lloc trobem en la llei un altre element de relació o confrontació amb la Directiva de Serveis. La previsió de la possibilitat que els ajuntaments regulin mitjançant ordenança o instruments de planejament la implantació d'establiments (articles 26 i 27 de la llei), i en aquest sentit prohibir-la, limitar-la o restringir-la per evitar-ne la concentració excessiva o garantir-ne la coexistència amb altres activitats humanes o socials. Cal tenir en compte que aquestes restriccions territorials són de les que la Directiva de serveis no admet llevat que siguin adoptades de forma justificada d'acord amb els principis que inspiren la Directiva de Serveis ( article 15).

No és que aquesta previsió sigui obertament contrària a la Directiva, ni molt menys, però si que cal que sigui justificada en cas d'adoptar-se una disposició normativa en aquest sentit per part d'un ajuntament. Aquest va ser el criteri de la Comissió Europea expressat en la resposta a la pregunta E-5403/2010 formulada al Parlament europeu pel grup parlamentari popular europeu ${ }^{21}$.

També en termes similars es va pronunciar el Tribunal Superior de Justícia de Catalunya $(\mathrm{TSJCat})^{22}$ en relació a una ordenança d'un municipi català que establia una distància mínima entre les activitats de locutori que si volguessin instal·lar. Tot i que aquestes activitats no es troben incloses en l'àmbit de la Llei 11/2009, els fonaments de la regulació municipal i la decisió del TSJCat, crec que són perfectament traslladables a l'aplicació del preceptes que ens ocupen. És a dir que correspon a les autoritats públiques, en aquest cas les locals la "càrrega de la prova" ${ }^{23}$, en relació a la justificació i proporcionalitat de la limitació de la llibertat d'establiment. Independentment de què

\footnotetext{
${ }^{20}$ Es sotmeten a comunicació la modificació no substancial dels establiments oberts al públic que comptin amb la llicència municipal corresponent; els establiments oberts al públic destinats a espectacles cinematogràfics; els establiments oberts al públic destinats a espectacles públics i activitats recreatives musicals amb un aforament autoritzat fins a 150 persones; establiments oberts al públic d'activitats de restauració amb un aforament autoritzat fins a 150 persones, i sempre que no disposin de terrassa o qualsevol altre espai complementari a l'aire lliure; les actuacions en directe en els establiments recollits en el catàleg de l'annex I. Per contra queden sotmesos a llicència prèvia les activitats que superen aquest paràmetres. També queden sotmeses a llicència ambiental de la Llei 20/2009 les discoteques fins a 150 persones d'aforament, les sales de ball fins a 150 persones d'aforament $i$ les sales de festes amb espectacle fins a 150 persones d'aforament.

21 Podeu consultar electrònicament el text de la pregunta $i$ el de la resposta a l'adreça http://www.europarl.europa.eu/plenary/es/parliamentary-questions.html

${ }^{22}$ Sentència del Tribunal Superior de Justícia de Catalunya, Sala C-A, de 10 de juliol de 2009.

${ }^{23}$ RODRIGUES, S., Les services publics locaux face au droit communautaire. Les exigences du marché intérieur, La Documentation francaise, 2007.
} 
existeixi un objectiu legítim per limitar el dret de lliure establiment i prestació de serveis, d'acord amb el Dret de la Unió cal que es justifiqui la restricció i la seva proporcionalitat amb l'objectiu a assolir.

Pel que fa a la Llei 20/2009, de prevenció i control ambiental de les activitats, s'ha de destacar la manca de tota referència a la Directiva de serveis per part del legislador català. És cert que aquesta norma sectorial s'empara en una Directiva comunitària específica, la Directiva 1/2008, del 15 de gener, de prevenció i control integrats de la contaminació. Però, des del meu punt de vista, també és pot mantenir que resta subjecta a la Directiva de Serveis, al menys en part, per diversos motius ${ }^{24}$.

En primer lloc perquè la transposició de la Directiva de prevenció i control integrats de la contaminació només abasta les activitats contingudes a l'annex I, i per tant tot i que la resta d'activitats que inclou la llei poden ser perfectament regulades pel legislador català en virtut del principi de major protecció ambiental que empara la legislació de la UE, això no les exclou de l'aplicació de la Directiva de Serveis, i per tant de cap manera es podria obviar la seva justificació.

En segon lloc perquè precisament estableix que les activitats, amb menor incidència ambiental, les de l'annex III de la Llei queden sotmeses al règim de comunicació prèvia, que com s'ha dit és una de tècniques d'intervenció que potencia la Directiva de Serveis.

Paga la pena també fixar-se, encara que no sigui directament aplicable a Catalunya, en la previsió continguda a l'apartat 1 de l'article 22 del Reial decret 2009/2009, de 23 de desembre $^{25}$, pel qual es modifica el Reglament de serveis de les corporacions locals, aprovat pel Decret de 17 de juny de 1955, que estableix clarament que "la apertura de establecimientos industriales y mercantiles podrá sujetarse a los medios de intervención municipal, en los términos previstos en la legislación básica en materia de régimen local y en la Ley 17/2009, de 23 de noviembre, sobre el libre acceso a las actividades de servicios y su ejercicio".

Tornant a l'aspecte concret de la desaparició dels permisos o llicències municipals d'obertura d'establiments per a les activitats de l'annex III (article 50), la Llei 20/2009 ha comportat la modificació d'ordenances o reglaments municipals que establien un

\footnotetext{
${ }^{24} \mathrm{Cal}$ tenir en compte que actualment es troba en tràmit al Parlament de Catalunya el Projecte de llei de promoció de l'activitat econòmica que modifica parcilament la Llei 20/2009.

${ }^{25}$ BOE núm. 313, de 29 de desembre de 2009.
} 
règim de permís o llicència municipal d'obertura d'establiments o activitats subjectes a comunicació prèvia previstes a l'annex III de la Llei 3/1998, doncs el nou text legal ja no deixa en mans dels ajuntaments escollir entre comunicació prèvia o permís, sinó que sempre haurà de sotmetre's el règim d'establiment d'aquestes activitats a la comunicació prèvia. Malgrat no ho expressi obertament la llei, no és això una manifestació del principi de proporcionalitat que predica la directiva?

Fixeu-vos, que fins i tot de forma clarament coherent amb aquest principi, la llei preveu la possibilitat que els ajuntaments sotmetin al règim de comunicació, enlloc de llicència prèvia, les activitats mòbils i de caràcter temporal de l'annex II associades a obres d'infraestructures, activitats de tractament de residus o similars en els termes que es prevegin reglamentàriament (article 54) o també algunes activitats de l'annex II subjectes al règim de llicència ambiental, situades en determinades zones urbanes $\mathrm{i}$ amb una qualificació urbanística determinada (article 7).

Pel que fa a un altre aspecte controvertit relacionat amb la Directiva de serveis, el silenci administratiu, la Llei 20/2009 (article 47) canvia la regla establerta a la Llei 3/1998 (la seva predecessora) del silenci positiu, que passa ara a ser negatiu. Aquesta nova regulació encaixa amb la previsió de la legislació bàsica estatal per a les activitats afectades per la Directiva de prevenció i control integrats de la contaminació, i a criteri dels redactors de la llei, amb la normativa ambiental europea (en matèria d'aigües, sorolls, residus, etc.) que exigeix imperativament l'obtenció de permís escrit. No obstant, en seu parlamentaria es van fer sentir algunes veus que posaren en dubte l'adequació d'aquesta previsió amb la Directiva de Serveis que en el seu article 13.4 proclama el silenci positiu llevat que una llei estableixi el contrari per raons imperioses $\mathrm{d}^{\prime}$ interès general ${ }^{26}$.

Cal tenir en compte novament, com a possible objecció al criteri mantingut pels redactors de la Llei 20/2009, que la llei bàsica estatal només afecta a les activitats de l'annex I i per tant en el cas de les activitats de l'annex II no n'hi ha prou amb invocar la raó imperiosa d'interès general (la protecció ambiental) sinó que cal a més justificar la mesura escollida. Igualment cal considerar que el concepte de "permís escrit" podria admetre matisos, com posa de manifest el TSJCat, quan afirma en la seva sentència de

\footnotetext{
${ }^{26}$ Veieu les compareixences relatives a la tramitació parlamentària de la llei de prevenció i control de les activitats que es publiquen al Diari de Sessions del Parlament de Catalunya sèrie C, núm. 588 de 10 de juny de 2009.
} 
10 de setembre de 2009 que l'exigència de permís escrit podria ser satisfeta mitjançant la certificació acreditativa del silenci administratiu ${ }^{27}$.

Al meu entendre, tot i que aquesta qüestió pot ser controvertida, considerant que el certificat del silenci és només un dels mitjans per acreditar la seva producció (article 43.4 de la Llei 30/1992) i el "perill" que podria suposar per al medi l'exercici d'una activitat amb incidència ambiental sense un control previ, des del punt de vista pràctic no es pot oblidar que la pròpia jurisprudència del TSJCat ha vingut exigint en aquest aspecte dos elements complementaris al transcurs del termini legalment establert per a la notificació de la resolució de l'expedient corresponent. En primer lloc, la prova de l'adequació del projecte de l'activitat a la legalitat (segons l'article 32.4 de la Llei 3/1998 no es podien adquirir per silenci facultats contraries a l'ordenament jurídic), i especialment a la urbanística, tenint en compte la relació entre una $\mathrm{i}$ altra matèria ${ }^{28} \mathrm{i}$ segon lloc, l'acta de control inicial favorable per exercir l'activitat ${ }^{29}$.

\footnotetext{
27 Veieu la STSJ de Catalunya, Sala Contenciosa administrativa, secció 3a, núm. de recurs 3/2007, núm. de resolució 791/2009, ponent J. Juanola Soler, que en el seu Fonament de Dret 3r si refereix en els següents termes: “(...) Las Administraciones demandadas alegan, asimismo, que no es posible obtener la autorización ambiental solicitada por silencio administrativo, por cuanto la normativa europea (Directiva 96/61 /CE) y la jurisprudencia del Tribunal de Justicia de la Unión Europea exigen "permiso escrito».
}

A lo que debe decirse que, para el supuesto de silencio administrativo positivo, el artículo 43.5, in fine, de la Ley 30/1992 del Régimen Jurídico de las Administraciones Públicas y del Procedimiento Administrativo Común, prevé la emisión obligatoria de la certificación acreditativa del silencio administrativo producido; certificación que satisface aquella exigencia de "permiso escrito».

En el presente caso, la Administración actuante no ha emitido dicha certificación, ni ha dictado resolución expresa. Por ello no puede apoyarse en su incumplimiento de las indicadas obligaciones, para alegar la falta de permiso escrito".

${ }^{28}$ Veieu entre altres els articles 17.1 d), 33.2 a), 39.1 i 52.1 de la Llei 20/2009, respecte a l'exigència de la compatibilitat de les activitats amb el planejament urbanístic.

${ }^{29}$ Veieu per totes la STSJCat, Sala contenciosa administrativa, secció $3^{\mathrm{a}}$, núm. de recurs 216/2008, núm. de resolución: 224/2009, ponent M. Taboas Bentanachs, de 10 de març de 2009, que, en el seu Fonament de dret tercer, si refereix en els següents termes:

“(...) Como reiteradamente esta Sección va sentando, debe señalarse que en la materia de titulación ambiental la aplicación automática del silencio positivo por el mero transcurso del plazo establecido no se comparte en aplicación, en materia urbanística, del artículo 5.2 de la Ley 2/2002, de 14 de marzo, de Urbanismo de Cataluña, como con posterioridad establece el artículo 5.2 del Decreto Legislativo 1/2005, de 26 de julio, por el que se aprueba el Texto Refundido de la Ley 2/2002, de 14 de marzo, de Urbanismo de Cataluña, como en materia ambiental se establece en los artículos 21.4 y 32.4 de la Ley 3/1998, de 27 de febrero, de la Intervención Integral de la Administración Ambiental y demás disposiciones concordantes.

Por todas y en la primera vertiente baste la cita de la Sentencia de la Sección de Casación de esta Sala, $n^{\circ} 7$, de 22 de abril de 2005 , y en la segunda vertiente baste la cita de nuestras Sentencias $n^{\circ} 151$, de 16 de febrero de 2007, $n^{\circ} 276$, de 7 de abril de 2008, $n^{\circ} 442$, de 2 de junio de 2008, $n^{\circ} 450$, de 3 de junio de 2008, $n^{\circ}$ 527, de 25 de junio de 2008, $n^{\circ} 801$, de 14 de octubre de 2008 y $n^{\circ} 953$, de 28 de noviembre de 2008 . 


\section{LA NECESSÀRIA RECONVERSIÓ DE LA INTERVENCIÓ DELS ENS LOCALS SOBRE LES ACTIVITATS AMB INCIDÈNCIA AMBIENTAL.}

La Directiva de Serveis en ha dut uns principis l'aplicació dels quals comportarà que la potestat d'intervenció dels ens locals sobre les activitats dels particulars, i també entre aquestes aquelles amb incidència ambiental, haurà de basar-se fonamentalment en els controls posteriors més que en les autoritzacions prèvies. Això imposa profundes reformes estructurals en l'organització dels serveis i l'actuació dels funcionaris públics dedicats a la policia administrativa. Veieu sinó com el règim de comunicació prèvia s'ha convertit en el més comú entre els aplicables a les activitats sotmeses a la Llei 11/2009 i la Llei 20/2009, sobre les quals intervenen els ens locals.

Si bé això representa un incentiu a l'hora de facilitar l'establiment i posada en funcionament d'activitats, també representa un repte per la necessitat de dotar-se d'una vertadera estructura inspectora, amb mitjans suficients $\mathrm{i}$ adequats, per part de l'Administració. A ningú se li escapa que tant nivell general com en l'àmbit local, la vessant inspectora ha estat fins ara, una de les menys desenvolupades de l’Administració ${ }^{30}$.

El nou règim de llicències i controls exigeix potenciar i donar valor a la funció inspectora. En un sistema fonamentat en el control formal previ en base a documents, com el que fins a la data venia sent el nostre, la cultura i les tècniques inspectores es troben molt debilitades. Els governs locals han d'afrontar avui un canvi d'orientació en aquest aspecte i també canvis importants en la dedicació i formació del seu personal, per a implantar gradualment un model d'inspecció eficient ${ }^{31}$. En aquest context els municipis petits no podran desenvolupar per si sols una funció inspectora adequada, ni tampoc executar eficaçment els controls posteriors. Per això caldrà apel·lar una vegada

Siendo ello asi bien se puede comprender que descansa en la carga de la prueba de quien haga valer el silencio positivo la necesidad de acreditar que el proyecto presentado es conforme a derecho y en el presente caso con la mera prueba documental que se dispone sólo puede llegarse a la conclusión que esa hipótesis dista de hallarse corroboratoriamente evidenciada, ni indiciariamente ni con suficiencia".

30 Veieu RIVERO ORTEGA, R. El Estado vigilante: consideraciones jurídicas sobre la función inspectora de la Administración, Tecnos, Madrid, 1999; i FERNÁNDEZ RAMOS, S., La actividad administrativa de inspección. El régimen jurídico general de la función inspectora, Comares, Granada, 2002.

${ }^{31}$ MERINO ESTRADA, V., MARTÍN FERREIRA, P., "Directiva de Servicios y Entidades Locales en Castilla y León", Impacto de la transposición de la Directiva de Servicios en Castilla y León, Consejo Económico y Social de la Comunidad de Castilla y León, 2009, p. 556. 
més al paper de col·laboració i assistència que les administracions supramunicipals (Diputacions i els Consells comarcals) tenen encomanat legalment.

El reforçament de la funció inspectora i de control posterior exigeix també un règim sancionador efectiu per als casos d'incompliment, que desincentivi les pràctiques fraudulentes. I caldrà també fer un bon ús de dues de les previsions que la nova legislació estableix en relació a les declaracions responsables i les comunicacions prèvies $^{32}$. Em refereixo en primer lloc a la clàusula de responsabilitat dels titulars de les activitats. Veieu per exemple allò que estableix l'article 52.5 de la Llei 20/2009 : "Un cop efectuada la comunicació, l'exercici de l'activitat es pot iniciar sota l'exclusiva responsabilitat de les persones titulars i tècniques que hagin lliurat les certificacions, els mesuraments, les anàlisis i les comprovacions (...)". No vol dir això que si 1'Administració no fa ús de les seves facultats d'inspecció i control quedi exonerada sempre i en tot lloc responsabilitat, però en tot cas aquesta haurà de ser apreciada només de forma subsidiària, i en cas que l'Administració hagi incomplert els seus deures de control, allò que coneixem com a culpa in vigilando. ${ }^{33}$

En segon lloc cal tenir també en compte la nova redacció de la Llei 30/1992, de 26 de novembre, de règim jurídic de les administracions públiques i del procediment administratiu comú, que en el seu article 71 bis i en relació amb la declaració responsable i la comunicació prèvia, estableix que "la inexactitud, falsedad u omisión, de carácter esencial en cualquier dato, manifestación o documento que se acompañe o incorpore a una declaración responsable o a una comunicación previa, o la no presentación ante la Administración competente de la declaración o comunicación determinará la imposibilidad de continuar con el ejercicio del derecho o actividad afectada desde el momento en que se tenga constancia de tales hechos, sin perjuicio de las responsabilidades penales, civiles o administrativas a que hubiera lugar". A més cal tenir també present que la resolució de l'Administració que declari aquestes circumstàncies podrà determinar la obligació de restituir la legalitat. Una previsió que si la posem en relació amb la normativa sectorial ambiental, sigui la Llei 20/2009, o les

\footnotetext{
${ }^{32}$ Sobre aquestes figures veieu RAZQUIN LIZARRAGA, J. A., "El impacto de la Directiva de Servicios en el procedimiento administrativo: Autorización, declaración responsable y comunicación.”, Revista Jurídica de Navarra, núm. 49, 2010, pp. 85-136.

${ }^{33}$ Veieu entre altres les SSTS de 25 d'abril 2010, Sala C-A, secció 6a i de 21 de novembre de 2007, de la mateixa Sala i Secció.
} 
sectorials relatives a sorolls, aigües, residus o altres vectors ambientals es converteix en obligació $^{34}$.

En definitiva es tracta de noves eines per a nous paradigmes, que haurem d'aprendre a emprar correctament.

\section{BIBLIOGRAFIA}

BIZET, J., Rapport d'information $n^{\circ} 199$ (2007-2008) fait au nom de la délégation pour l'Union européenne, presentat al Senat francès el 7 de febrer de 2008, http://www.senat.fr/rap/r07-199/r07-1991.pdf .

CANO MURCIA, A., El nuevo régimen jurídico de las licencias de apertura, El Consultor de los Ayuntamientos (La Ley), Madrid, 2010.

DE LA QUADRA-SALCEDO FERNÁNDEZ DEL CASTILLO, T. (dir.), El mercado interior de servicios en la Unión Europea. Estudios sobre la Directiva 123/2006/CE relativa a los servicios en el mercado interior, Marcial Pons, Madrid-Barcelona-Buenos Aires, 2009.

DE LA QUADRA-SALCEDO FERNÁNDEZ DEL CASTILLO, T., "Libertad de establecimiento y de servicios: ¿Reconocimiento mutuo o país de origen?, Revista española de Derecho Administrativo, núm. 146, 2010.

FERNÁNDEZ RAMOS, S., La actividad administrativa de inspección. El régimen jurídico general de la función inspectora, Comares, Granada, 2002.

FERNÁNDEZ RODRÍGUEZ, T-R, "Un nuevo Derecho Administrativo para el mercado interior europeo”, Revista Española de Derecho Europeo, núm. 22, 2007.

GONZÁLEZ GARCÍA, J., "La transposition de la Directive services. À propos de deux problèmes: la Directive face au droit primaire et les régimes d'autorisations", Chaire Mutations de l'action publique et du droit public (MADP), Sciencies Po, 2010.

MERINO ESTRADA, V., MARTÍN FERREIRA, P., "Directiva de Servicios y Entidades Locales en Castilla y León", Impacto de la transposición de la Directiva de

\footnotetext{
${ }^{34}$ Veieu RAZQUIN LIZARRAGA, J. A., "El impacto de la Directiva de servicios...” cit., p. 121.
} 
Servicios en Castilla y León, Consejo Económico y Social de la Comunidad de Castilla y León, 2009.

MUÑOZ MACHADO, S., "Ilusiones y conflictos derivados de la Directiva de Servicios", Retos y oportunidades para la transposición de la Directiva de Servicios, Circulo de Empresarios, Madrid, 2009.

PERDIGÓ SOLÀ, J., CHOY TARRÉS, A., LIGÜERRE CASALS, J., Comentaris a la Llei 20/2009, de 4 de desembre, de prevenció i control ambiental de les activitats, Generalitat de Catalunya, Departament de Medi Ambient i Habitatge, Barcelona, 2010.

PERNAS GARCIA, J. J., “Técnicas preventivas de protección ambiental y normativa de servicios. análisis particularizado de la evaluación de impacto ambiental y de la ordenación administrativa de la gestión de residuos", Revista Catalana de Dret Públic, núm. 2, 2010.

RAZQUIN LIZARRAGA, J. A., "El impacto de la Directiva de Servicios en el procedimiento administrativo: Autorización, declaración responsable y comunicación.”, Revista Jurídica de Navarra, núm. 49, 2010.

RENYER ALIMBAU, J., FONT MONCLÚS, J. A., SABATÉ VIDAL, J. M., Criteris per a l'adaptació de la normativa local a la Directiva de Serveis, 2006/123/CE, de 12 de desembre, relativa als serveis en el mercat interior, Càtedra d'Estudis Jurídics Locals Enric Prat de la Riba, Barcelona, 2010.

RODRIGUES, S., Les services publics locaux face au droit communautaire. Les exigences du marché intérieur, La Documentation française, Paris, 2007.

RIVERO ORTEGA, R. El Estado vigilante: consideraciones jurídicas sobre la función inspectora de la Administración., Tecnos, Madrid, 1999.

SALVADOR ARMENDÁRIZ, M. A., VILLAREJO GALENDE, H., "La Directiva de Servicios y la regulación de los grandes establecimientos comerciales en Navarra", Revista Jurídica de Navarra, núm. 44, 2007. 